This is a pre-print versión of: Rovira-Esteva, Sara. 2005. "What do we leave behind when failing to translate a "Chinese Dead Metaphor?". A: Branchadell, Albert; West, Margaret (eds). Less Translated Languages, Amsterdam/ Philadelphia: John Benjamins Publishing Company. (Benjamins Translation Library, 58). Pp. 237-254. ISBN: 9027216649

\title{
What Do We Leave behind When Failing to Translate a Chinese \\ Dead Metaphor?
}

Sara Rovira-Esteva

\section{Introduction}

Almost everyone agrees that the mastering of Chinese measure words is a difficult point within the teaching and learning of Chinese. But what seems to be even more challenging is grasping and accurately translating them into other languages.

The fact that they do not exist as an independent category in Western grammars probably explains why linguists have neglected them for so many years. We also believe that the different linguistic approaches used so far have failed to provide satisfactory data relevant to translation purposes. Nowadays, there are three facts jeopardising good translation practices concerning Chinese measure words, namely, the widespread belief that they are unique to Chinese and thus cannot be translated into Western languages, the habit of providing 
only one word in a foreign language for a given Chinese measure word, as if there was a fixed linguistic equivalent, and the idea that they are redundant. From our point of view, these approaches are too simplistic, but unfortunately are too common. Just recently a few works highlighting the importance of this linguistic phenomenon have been published:

汉语里有一类词, 它们的表达功能是很特殊的: 有了它们, 形象描 写得更为生动; 有了它们, 感情抒发得更为深切; 有了它们, 色彩表 现得更为鲜明;有了它们，文笔显得更为简练。(张向群 1995) ${ }^{12}$

This completely new approach is a promising one, since it sets up the basis for a more holistic approach including all levels of language and aspects related to discourse, instead of considering this phenomenon as a superfluous, merely morphological one, as many uninformed people do. Zhang Xiangqun adds:

量词是具有艺术个性的词类，它主要使语言充满视觉的光辉，以自 己的艺术力量生动地显示汉语的风采，因此它的修辞作用是不可低 估的。我们要说好话，写好文章，对量词需要给予足够的重视。当 然，这种重视，决不是号召人们滥用只会造成混乱，有损于语言的 健康。量词用好了，我们的语言将会表达得更准确，更鲜明，更生

动。（张向群 1995） ${ }^{3}$ 
In this paper we will show with numerous examples in Catalan and English how measure words are used in Chinese discourse and why more attention should be paid to them, both in teaching and in translating.

\section{A Cognitive and Linguistic Tool for Categorisation}

All languages categorise in one way or another and there is usually more than one overlapping classification system at work. What is intriguing about Chinese is the fact that nouns are further categorised by measure words. That means that a given entity, besides belonging to the category "table", for example, belongs also to the category of objects with a flat surface, so we often combine it with 张 (zhangl). What is even more interesting is that this second categorisation is not fixed, but depends on circumstances:

From a semantic, cognitive, and cultural point of view, the function of classifiers is "to communicate a few especially important classes that objects fall into by virtue of the way we interact with them. (Denny 1976) 
Each category of measure words embraces items apparently very different from each other (especially in the eyes of an outsider). For example, 道 (dào, way), categorises nouns such as crevice, ray, eyebrow, river, line and wrinkle. Although they all look very different to us, we can still find similarities among them, such as the fact that they all have a long and slender shape. This means that the formation of the category 道(dào) is not arbitrary but there is a semantic motivation. If we don't know cultural data or historical changes, then they might look arbitrary to us:

Linguistic categories are typically complex: they group together, and treat as equivalent for certain purposes, a variety of distinct and sometimes quite disparate elements. Though similar to varying extents, these elements are not always susceptible to a uniform characterisation affording absolute predictability of class membership: i.e. it is not always possible to find a description valid without qualification for all class members and inapplicable to all non members. Hence it cannot in general be presumed that membership in a linguistic category is a predictable, all-or-nothing affair. Membership is commonly a matter of degree, resistant to strict delimitation, and subject to the vicissitudes of linguistic convention. (Langacker 1987: 369-370.) 
According to cognitive linguistics, then, categories are fuzzy and membership depends on the degree of family resemblance with the prototype. The association lines among category members are not necessarily drawn between the entities and the prototype, but between one entity and another which is similar and has something in common with it. Since there are not clear boundaries between categories, some members are prototypical and others are peripheral, and thus their membership is dubious or vacillating. Thus it is not necessary that all members in one category share a common characteristic, or even that they share a common characteristic with the prototype. Association possibilities are multiple, which explains the lack of homogeneity within a category.

Tai and Wang (1990) studied the association processes underlying the creation of the category 条 (tiáo, long and slender object) and its relationship with other categories cognitively similar. According to their study, 鱼 (yú, fish), 裤子 (kùzi, trousers) and 腿(tui3, leg) are central members of this category; on the other hand, 街(jiel, road), 河 (hé, river), 路 (lì̀, way) and 影子 (ying3zi, shadow) are members by natural extension, that is, they belong to this category because they are similar or have something in common with the central members. Finally, 新闻 (xinlwén, news), 意见 (yijiàn, opinion) and 理 由(li3yóu, reason) are members by metaphorical extension. This research is very interesting because it shows how, starting from a set of prototypes and 
following the principle of family resemblance, other new members have joined the category.

Another important aspect we should take into account is the possibility of categorising the same entity in a variety of different ways. The fact that we often feel dubious about the best categorisation of an entity shows that the same entity allows different kinds of categorisation, which means that categorisation is not a matter of true or false. It also shows that categories are not well defined and that boundaries among them are fuzzy. As we can see, the objects in the following examples are categorised according to different parameters (shape, function, etc.):
(1)
一只筷子
a [one of a pair] chopstick
VS.
一根筷子
a [long and thin entity] chopstick
（2）一把椅子
a [entity with a handle] chair
VS.
一张椅子 a [entity with a flat surface] chair

We should be aware of the fact that every entity has many different characteristics and can be seen from very different points of view. Thus different situations can also reveal the different aspects of this entity, which can be conveyed with different measure words. Therefore, there is no one measure word that is better than another, it all depends on the context and the speaker's 
personal point of view. The different choices we make when creating a text reflect specific aspects of the entity in question:

[...] our present concern is with a broader phenomenon of which variable designation is only a special case: the ability of speakers to construe the same basic situation in many different ways, i.e. to structure it by means of alternate images. The contrasting images imposed on a scene amount to qualitatively different mental experiences. Consequently, the image embodied by a linguistic expression -the conventionally established way in which it structures a situation- constitutes a crucial facet of its meaning.

\section{$[\ldots]$}

Grammatical structure is based on conventional imagery, which reflects our ability to construe_a conceived situation in alternate ways. The full conceptual or semantic value of a conceived situation is a function of not only its content $[\ldots]$ but also how we structure this content with respect to such matters as attention, selection, figure/ground organization, viewpoint, and level of schematicity. In regard to all of these we are capable of making adjustments, thereby transforming one conceptualization into another that is roughly equivalent in terms of content but differs in how this content is construed [...]. (Langacker 1987: 138) 
Let's see some examples from literary works where the moon is categorised in many different ways. Some of these expressions invoke the same domain (i.e. reality) but contrast by choosing alternate profiles (images) within this common base:

(3)

a. 她的眉毛是像杨柳的叶子一样尖, 但你的眉毛却是像一钩 噺月。（叶君健《山村》）

b. Les seves celles són igual de punxegudes que les fulles d'un salze, les teves, en canvi, són com una lluna creixent. (Ye Junjian, El Poblet de la Muntanya)

c. Her eyebrows are just as sharp as the leaf of a willow; yours, on the other hand, look like a crescent moon. (Ye Junjian, The little mountain village)

a. 这一天的晚上, 海上有一弯眉毛似的新月照着。（巴金《 家》)

b. Aquell dia al vespre, sobre el mar hi brillava una lluna creixent corbada com una cella. (Ba Jin, La Família)

c. That evening, there was a crescent moon curved like an eyebrow shining above the sea. (Ba Jin, Family) 

大星。（冰心《寄小读者》）

b. El cel era d'un blau maragda, amb una lluna daurada i tensa com una corda. No gaire lluny, enfront la part còncava de la lluna, hi havia suspesa una gran estrella (Bing Xin, Carta als joves lectors)

c. Emerald blue sky, with a golden moon tense like a string. Not far away, there was a big star hanging in front of its concave side. (Bing Xin, Letter to young readers)

(6)

a. 天上已经升起一眉新月。（魏巍《东方》）

b. Al cel ja s'havia enlairat una lluna nova com una cella. (Wei Wei, Orient)

c. A new eyebrow-like moon had already risen in the sky. (Wei Wei, The East)

(7)

a. 茫茫无际大森林的顶梢, 是㖓红的天, 一牙新月正斜挂在 阿尔卑斯雪山角上。（萧乾《南德的暮秋》）

b. A les copes del bosc sense límits, quan ja havia caigut el sol, una rodanxa de lluna nova justament penjava de la punta de les muntanyes nevades dels Alps. ( Xiao Qian, Tardor avançada a l'Alemanya del sud) 
c. At the top of an endless forest, when the sun had already gone down, a slice of new moon was barely hanging from the summit of the snowy mountains of the Alps. (Xiao Qian, Late Autumn in Southern Germany)

(8)

a. 看见岸上歪过来的一株柳树, 一瓣黄月朦胧。（贾平凹《 浮躁》）

b. Va veure un salze sinuós a la ribera i la llum nebulosa d'un pètal de lluna. (Jia Pingwa, Inquiet)

c. He saw a waving willow by the shore and the nebulous light of a petal-like moon. (Jia Pingwa, Rash)

(9)

a. 涌了半弓明月, 浮着万叠银波, 不声不响, 在浓淡的两岸 山中, 往东流出的, 是东汉逸民垂钓的地方。（郁达夫《还 乡病者》)

b. Va emergir mig arc de lluna, flotaven mil capes d'ones platejades, no sentia ni un brogit ni un soroll, entre el clar i fosc de les muntanyes a banda i banda de la ribera discorregué cap a l'est. Era el lloc on pescaven amb canya els ermitans de la dinastia Han de l'Est. (Yu Dafu, El malalt que torna a la terra natal) 
c. A half moon arch emerged, thousands of layers of silver waves were floating, there was not a sound, and in between the darkness and brightness of mountains on each side of the shore, it rolled to the East. That was the place where hermits used to fish with a rod during the East Han Dynasty. (Yu Dafu, Ill because missing his birthplace)

a. 其时云影翻开, 露出冷冰冰亮晶晶的一轮明月。（睢秋白 《饿乡纪程》）

b. En aquell moment, els núvols es van obrir i van deixar al descobert una lluna com un disc, centellejant i freda com el gel. (Qu Qiubai, Anals de Vila-gana)

c. At that moment, the clouds parted and revealed a disk-like moon, shining and cold as ice. (Qu Qiubai, Annals of Hungryvillage)

(11)

a. 一盘水银似的明月悄悄地从东转到南, 又从南转到西边天 空了。（王林《叱咤风云》）

b. Una lluna plena i mercúrica va rodolar silenciosament d'est a sud i després del sud al cel de l'oest. (Wang Lin, Exit)

c. A full mercuric moon rolled silently from East to South and then from the South to the Western sky. (Wang Lin, Success) 
a. 不到一刻钟, 便见沧波万里, 银光如泻, 二丸冷月, 傲视 天空。（陈衡哲《再游北戴河》）

b. Abans d'un quart d'hora, ja es van veure una immensitat d'ones blau marí i raigs platejats que brollaven d'una bola de lluna freda, que mirava altiva el cel. (Chen Hengzhe, Una altra visita a Beidaihe)

c. Before a quarter of an hour had passed, countless dark blue waves could be seen, and the cold ball of the moon, pouring silver rays and looking down on the sky. (Chen Hengzhe, Visiting anew Beidaihe)

(13) a. 一梳月亮像形容未长成的女孩子, 但见人已不羞缩, 光明 和轮廓都清新刻露, 渐渐可烘托夜景。（钱钟书《围城》）

b. Una lluna com una pinta, que semblava una nena que encara no hagués crescut, però que ja no s'avergonyia en presència d'estranys. La seva llum i perfil frescos i penetrants poc a poc inundaren el paisatge nocturn. (Qian Zhongshu, La ciutat assetjada)

c. A moon like a comb, similar to a girl that has not yet grown up, but who no longer blushes at the sight of strangers. Its fresh 
and sharp light and profile slowly flooded the night landscape. (Qian Zhongshu, Besieged town)

Among all these examples there are dead metaphors and creative metaphors. For example 一钩月 (yil goul yuè), a [hook] moon, 一轮月 (yil lún yuè), a [disc/wheel] moon, and 一弯月 (yil wanl yuè), a [curved] moon, can all be considered dead metaphors, since they are the usual ways of referring to the moon in Chinese. The first underlines the sharp edges of a crescent moon, the second refers to a full moon and the last underlines the rounded profile of the moon rather than the edge. The first and the third examples may refer to the same reality, but the point of view or pinpointed characteristic are not the same. Nevertheless, they all belong to conventional imagery. As we have just said 弯(wanl) is an adjective meaning curved and, as a measure word, it is used basically for eyebrows (especially women's) and the moon. 钩 (goul, hook) is a measure word exclusively for a crescent or waning moon. On the other hand, 丸 (wán, ball), 盘 (pán, plate) and 牙 (yá, tooth/ slice) are used for many round or sliced objects, but these are usually smaller. Nevertheless, these metaphors are easily interpreted and in the process of becoming dead metaphors. We cannot say the same about the rest, since their use is unusual: 弦 (xián, string/cord) 瓣 (bàn, petal), 弓 (gong1, arch) and 眉 (méi, eyebrow). Except for the second example, none of these characters have the official status 
of measure words, so they are personal creations of these authors or creative metaphors (maybe in the process of becoming dead metaphors).

\section{A Powerful Tool for the Creation of Metaphorical Expressions}

We often associate metaphor and metonymy with literary style but actually they are present in our everyday thought and speech, since they are a cognitive device to process abstract and complex information through more concrete, simple and familiar concepts. In Chinese, there are metaphors and metonymies used in a similar manner as in English or Catalan. Nevertheless, if we analyse the discursive use of Chinese measure words, we will realise that they are also a cognitive tool for the creation of powerful and concise metaphorical and metonymical expressions, sometimes of great beauty:

一提到修辞，可能有人会立刻想到比喻，拟人，夸张等许多修辞 格, 同时脑海里又出现了一大堆形容词, 动词, 名词, 而他们往 往想不到量词的修辞作用。其实仔细推敲一下, 在特定的语境里, 量词的修辞效果比起其他词类的修辞效果来并不逊色，而且某些修 辞现象野和量词有着密切的关系。（张向群 1995） ${ }^{4}$ 
If we use a part to refer to the whole, we have a metonymy. This transfer takes place because there is physical contiguity and the goal is to underline one of the objects' characteristics. Measure word use is often the result of a metonymic cognitive process. Let's look at some examples with their literal English and Catalan equivalents, very few of which coincide with expressions in these two languages:

- Using one part to categorise the whole:

(14) 头 (tóu) head: 一头牛/ a head of cattle/ un cap de bestiar

(15) 口 (kou3) mouth: 一口猪/ a [mouth] pig/ un [boca] porc

(16) 顶 (ding3) ceiling: 一顶帽子/ a [ceiling] hat/ un [sostre] barret

(17) 尾 (wei3) tie: 一尾鱼/a [tie] fish/ un [cua] peix

- Usage of a contiguous object to categorise the whole:

(18) 笔 (bi3) brush: 一笔好字/ a [brush] good calligraphy/ una [pinzell] bona cal·ligrafia

(19) 刀 (daol) knife: 一刀肉/ a cut of meat/ un tall de carn

(20) 床 (chuáng) bed: 一床被子/ a [bed] sheet/ uns [1lit] llençols

Let's look at more examples from several prestigious Chinese writers: 
(21)

a. 那时我母亲主持一个大家庭，上下有二十多口。（冰心《 关于女人》)

b. En aquells temps, la mare estava al càrrec d'una gran família, amb grans i petits hi havia més de vint boques. (Bing Xin, $\mathrm{Pel}$ que fa a les dones)

c. In those times, my mother supported a big family; all together there were more than twenty mouths. (Bing Xin, Concerning women)
a. 又不知王妈睡觉时, 会不会忘记关上一扇门或一扇窗。

\section{(叶圣陶《潘先生在难中》)}

b. A més, no sabíem si la senyora Wang havia pogut oblidar-se de tancar el batent d'una porta o d'una finestra en anar-se'n a dormir. (Ye Shengtao, El senyor Pan en dificultats)

c. We didn't know whether Mrs. Wang could have forgotten to shut the leaf of a door or of a window when she went to sleep. (Ye Shengtao, Mr. Pan in trouble)

As we have previously mentioned, when speaking of metaphors, we should distinguish between two very different usages. The first are called dead or conventionalised metaphors. Speakers are very seldom aware of them. The 
second are invented, which are the result of creativity, and need to be decoded. The use of dead metaphors is quite automatic, similar to the choice of grammatical genre in Catalan or Spanish. Creative metaphors, on the other hand, need both a creative effort from the author and a decodification effort from the receiver of the message, as with any other literary form. In any case, metaphor is a mechanism of subjectification, since it underlines some traits and hides others. It includes the speaker's point of view, which we should take into account when translating a text. Let's see with examples taken from literature how authors handle dead and creative metaphors to express their meanings inside their work:

a. 在证券交易所内, 他也算得上一条好汉。》（茅盾《赵先 生想不通》)

b. A la seu de la borsa de valors, també se'l pot considerar tot un heroi. (Mao Dun, El senyor Zhao no ho entén)

c. In the stock-market headquarters, he can also be considered $\underline{\mathrm{a}}$ hero. (Mao Dun, Mr. Zhao does not understand)

(24)

a. 我们只是一叶扁舟, 应该任凭波浪把我们载到什么地方 去。（巴金《鬼一一个人的自述》）

b. Nosaltres no érem més que una barqueta que, talment com una fulla, havia de seguir la voluntat de les ones que ens portarien a 
algun 1loc. (Ba Jin, Esperits -Les experiències d'una persona sola)

c. We were only a little boat, forced, like a leaf, to go where the waves would take us. (Ba Jin, Spirits -The experiences of a single person)

(25)

a. 也是自从九一以后, 就再没有一丝声息的民族主义文学者 们, 也来加以冷冷的讪笑。（鲁讯《新药》）

b. Va ser també després del 18 de setembre que no es va tornar a sentir ni un fil de veu dels literats nacionalistes i sí un riure fred i desconfiat. (Lu Xun, Nova medecina)

c. It was also after September the $18^{\text {th }}$ that there wasn't the slightest sound coming from the nationalist literati, except for a cold and distrustful laugh. (Lu Xun, New Medicine)

(26)

a. 我起先只在静听着柔橹划水的声音, 然后却在黑影里看出 了一星船家在吸着的长烟管头上的烟火。（郁达夫《钓台的 春画》)

b. Al principi, només vaig sentir enmig del silenci el so suau dels rems fregant l'aigua. Després, en canvi, vaig veure enmig de la foscor una bola de fum que sortia de la llarga pipa que fumava el barquer. (Yu Dafu, Quadre de primavera al moll) 
c. At the beginning I heard in the silence only the soft sound of the rowing in the water, but afterwards, I saw a ball of smoke coming from the boatman's long pipe in the middle of the dark. (Yu Dafu, Spring picture at the pier)

a. 她的思路被一缕萧声打断。》（李英儒《野火春风斗古 城》)

b. Un fil de veu desolada va interrompre el curs del seu pensament. (Li Yingru, L'incendi a la planura $i$ el vent de primavera colpegen la vella ciutat)

c. Her train of thoughts was interrupted by a low desolate voice. (Li Yingru, The fire and the wind struck the old city)

(28)

a. 虽然生活在污秽和贫穷里, 只要有人给他们带来一线希望 ，他们会相信光明就在眼前。（巴金《利娜》）

b. Malgrat que viuen immersos en la brutícia i la pobresa, només que algú els porti un bri d'esperança, creuran que tenen la llum davant dels seus ulls. (Ba Jin, Lina)

c. Although they live surrounded by filth and poverty, if someone would only bring them a ray of hope, they would believe there was light before their eyes. (Ba Jin, Lina) 
a. 一片寂静包裹着整个山林, 田园, 天和分娩的大地。（徐 迟《狂欢之夜》)

b. Un llençol de calma embolicava tota la muntanya, els camps, el cel i la terra que estava donant a llum. (Xu Chi, Nit de luxúria) c. A sheet of calm wrapped the entire mountain, the fields, the sky and the life-giving earth. (Xu Chi, Lustful Night)

(30)

a. 一扇一扇的大红蝴蝶早就从如今这黑色瀑布一大波浪卷发 上飞离了。(孔捷生《南方的岸》)

b. Un gran nombre d'immenses papallones vermelles de seguida van sortir volant de la cresta de les eriçades ones de l'avui negra cascada tot batent les ales. (Kong Jiesheng, La riba del sud)

c. A large number of huge red butterflies immediately flew from the rough waves of the now black waterfall beating their wings. (Kong Jiesheng, Southern Shore)

(31)

a. 芳影此时觉得有说不出的一种情绪, 她嘴边微微显露—弧 冷冷的笑容, 她的眼望着窗上的花影, 依旧是因风摇曳。 (张爱玲《吃茶》)

b. La Fangying en aquell moment li va semblar que sentia unes emocions que no podia explicar, a la comissura dels llavis se li 
va dibuixar lleugerament l'arc d'un somriure fred. Els seus ulls miraven l'ombra de les flors de la finestra, que continuaven balancejant-se amb el vent. (Zhang Ailing, Bevent te)

c. Fangying felt then a kind of emotion she could not express. At the corner of her mouth appeared the slight arch of a cold smile. Her eyes were looking at the shadow of the flowers on the window, which were still waving with the wind. (Zhang Ailing, Drinking tea)

a. 两年前夫人的心，好比是一块海绵，她的每一滴思想，碰 上就被吸了进去。》（茅盾《创造》）

b. Dos anys enrere el cor de l'esposa havia estat com una esponja, cada gota del seu pensament, tan bon punt hi entrava en contacte, era absorbida. (Mao Dun, Creació)

c. Two years ago, his wife's heart had been like a sponge, each drop of her thoughts absorbed upon reaching it. (Mao Dun, Creation)

(33)
a. 晓荷一闭眼, 从心中挖出一小块智慧来。》（老舍《四世 同堂》) 
b. En Xiaohe, tan bon punt va tancar els ulls, va furgar dins del seu cor i en va treure un petit tros de saviesa. (Lao She, Quatre generacions sota un mateix sostre)

c. As soon as Xiaohe shut his eyes, he searched his heart and took out a small piece of wisdom. (Lao She, Four generations under the same roof)

a. 码头泊着小小的渔船, 透过船篷是红红的灯, 看得见古铜 色的脊梁护卫着一窝甜甜的梦, 梦中的渔家的孩子像黑鳗一 样扭动着。（舒婷《到石码去》）

b. Al moll hi havia ancorada una barqueta de pescadors, a través de la vela passava una llum ben vermella que deixava veure una espatlla de color coure vell que protegia un niu de somnis dolços. El fill del pescador, que estava somiant, es regirava com una anguila negre. (Shu Ting, Fins a la fita de pedra)

c. There was a little fishing boat anchored at the pier. An intense red light soaked through the sail and a shoulder, tanned the colour of old copper, protecting a nest of sweet dreams, could be seen. The dreaming fisherman's son was tossing like a black eel. (Shu Ting, To the milestone) 
a. 他望着我, 眼睛里竟出奇地一汪平静, 像那个晚上淡淡的 月色。（张大春《鸡翎图》）

b. Ell m'esguardava amb uns ulls com un estany d'una calma excepcional, com la clara llum de lluna d'aquell vespre. (Zhang Dachun, El dibuix de plumes de gall)

c. He was staring at me, in his eyes the look of a tranquil lake, just like the moon's bright light that evening. (Zhang Dachun, The picture of a cock's feathers)

a. 车过了松江, 风景又添了一味和平的景色。（郁达夫《还 乡记》)

b. Quan el cotxe va passar de llarg el riu Song, el paisatge es va omplir de l'olor d'una vista pacífica. (Yu Dafu, Diari de tornada a casa)

c. When the car drove past the Song river, the landscape was filled with the smell of a peaceful view. (Yu Dafu, Going home diary)

The use of 条 (tiáo, branch), for long and narrow things, with hero (23) might be related to the fact that in our collective imagery, we think of a hero as a handsome man, one who is probably strong and has a slender figure. 叶 (yè, leaf) in (24) underlines the fragile aspect of the little boat, since the image it 
evokes is that of a tree leaf floating on the water and led by the stream. 丝 (sil, thread), 缕 (lü3, thread), 线 (xiàn, thread), in (25), (27) and (28) respectively are, in fact, synonyms. They all refer to very small or thin things, especially if they are abstract entities. 片 (piàn, slice / extension) in (29), on the other hand, when used metaphorically refers to things that cover a big surface. The use of 扇 (shan1, fan or leaf) with butterflies in (30) implies a metaphor, where the butterflies' wings are compared to a fan, underlying their flapping movement. Especially shocking is the use of 滴 (dil, drop) and 块 (kuài, bit) with intangible entities, such as thought and wisdom in (32) and (33), respectively. The association of 窝 (wol, nest) in (34) with dream gives the idea of a very sweet feeling, since we usually dream in our beds, when we feel comfortable, warm and protected. The use of 汪 (wangl) in (35), used for liquids, and 味 (wèi) in (36), used for smells or tastes, with calm and landscape, respectively, are cases where there has been a shift in the sensory domain, which is in fact what creates the special rhetorical effect. All these examples show that there are different possible ways of interpreting reality, which can be explained with different images, according to communicative needs. Thus there is a dynamic element linked to the action of the speaker towards the message transmitted.

Chinese has many resources to create metaphorical and metonymical images but none as perfect, from the point of view of linguistic economy, as Chinese measure words. These images are often conventionalised and the word's metaphorical strength is weakened, so speakers are rarely aware of 
them, as is the case with 叶 (yè, leaf), 丝 (sil, thread), 线 (xiàn, thread), 缕 (lü, thread) and 片 (piàn, slice / extension). We have to be aware of the fact that this categorisation system is flexible enough to allow speakers to use it according to their own abilities and needs:

Classifiers - unlike noun classes- may vary in use between different styles within a speech community: It is generally the case that higher, more formal (often, written) registers will feature the most extensive set of classifiers, with informal speech using a smaller number of classifiers, and perhaps also employing them less often. (Dixon 1986: 110)

According to cognitive linguistics, semantics is linked to pragmatics, i.e., denotative aspects cannot be analysed separately from connotative ones. Both the situational context and the cultural context are necessary to understand a text. Besides, since cognitive linguistics assumes that the speaker is involved in the message produced, the choice of the measure word in each case is not automatic but subjective, motivated by the intention and conditioned by the message intended. The choice of one measure word or another is thus explained by the need to communicate; it is not arbitrary. If the speaker's point of view is neutral, i.e., (s)he does not want to underline any specific aspect of the entity, then (s)he will choose the most handy option, according to personal usage 
(idiolect) or social usage (dialect), which will probably be a prototypical measure word for that entity and the one we will teach to our language students. There is a dynamic aspect linked to the speaker's action regarding his or her messages. There are different factors involved, such as associations, impressions, feelings that are part of the speaker's experience. Nevertheless, not all the associated elements have the same value or importance, so what we express are, in fact, those parts of the event that attract our attention.

Our conceptual system is organised according to our inner poetry and this is reflected in the figurative conceptions we express through language. These conceptualisations are often wholly conventional. As we have seen, metaphor and metonymy are very much related to linguistic structure and play an essential role in many categorisation processes, as well as in the articulation of certain grammatical phenomena.

The culture-specific words and grammatical constructions of a language are conceptual tools which reflect a society's past experience of doing and thinking about things in certain ways. As a society changes, these tools may be gradually modified and discarded. In that sense the outlook of a society is never wholly 'determined' by its stock of conceptual tools, but it is clearly influenced by them. Similarly, the outlook of an individual is never fully 'determined' by his or her native language, one's conceptual perspective on life is clearly influenced by his or her native language. 
Much the same can be said about communicative style. An individual's communicative style is not rigidly determined by the cultural scripts which he or she internalizes while growing up in that culture. There is always room for individual and social variation, and for innovation. But the communicative style of both society and individual cannot escape the influence of the 'cultural rules' of communication. (Dirven; Verspoor 1998: 155)

This means that we will have to teach our language and translation students that each culture organises reality in a different way, each entity can be categorised in a variety of different ways, and that conventional imagery can potentially be enriched by the creation of new personal metaphors.

\section{Translation of Measure Words}

Although neither Spanish nor English are considered classifier languages, we often find words and syntactic structures that can be considered equivalent when translating a measure word from Chinese. The fact that our grammars do not have a special category called classifiers or measure words because they are included in other categories, such as nouns, adjectives or verbs, does not mean that we cannot compare them to Chinese in this respect 
and try to find equivalents. We will often need to use different linguistic resources to convey the meaning of a Chinese expression using a classifier; sometimes we'll find a similar vehicle, sometimes we will express the same meaning with a different rhetorical form and, sometimes, we simply won't find a way, as in any other translation context.

Below is a list of English expressions that can be equivalent to Chinese measure word constructions (just as an example): a cluster of houses, a clamour of voices, a stream of pedestrians, a bundle of belongings, a few strings of cash, the crowds of onlookers, a bowl of tea, a few drops of rain, rays of candlelight, the red disk of the sun, a lock of hair, two ingots of silver, paths of sentiment, tendrils of smoke, a wave of feeling, patches of weeds, piles of roof tiles, hunks of rotting wood, stands of bamboo, a stitch of clothing, a thick coat of dust, a wisp of chill air, shreds of sound, a kind of chant, a layer of earth, a kind of tranquillity, clusters of jade-green bamboo, herds of cows and sheep, a speck of dust, stalks of green bamboo, a riot of blossoms, a basin of cold water, clouds of dust, a full moon, a few strands of hair, etc.

As we have seen in the previous section, measure words are not redundant but, in fact, can be very challenging from the translation point of view. Sometimes we will be able to translate the Chinese expression quite literally as in: 一束花儿 (yil shù huar1), a bunch of flowers, or 一滴雨 (yil dil $y u 3$ ), a drop of rain. Sometimes we will have to find the accurate equivalent according to the context, as in the following examples, since the same measure 
word in Chinese can have numerous equivalents in English and Catalan, depending on the noun they precede, because of collocation patterns:

(37) 一群沙丁鱼 $\rightarrow$ a shoal of sardines/ un banc de sardines

(38) 一群狮子 $\rightarrow$ a pride of lions/ una manada de lleons

(39) 一群牛 $\rightarrow$ a herd of cows/ un ramat de vaques

(40) 一群强盗 $\rightarrow$ a gang of thieves/ una banda de lladres

(41) 一群马 $\rightarrow$ a drove of horses/ una cavallada

(42) 一群野鸭 $\rightarrow$ a flock of wild ducks/ una colla d'ànecs salvatges

(43) 一群蜜蜂 $\rightarrow$ a swarm of bees/ un eixam d'abelles

(44) 一群姑娘 $\rightarrow$ a group of girls/ un grup de noies

Most of the time, though, we will have to find other expressive means to convey the same meaning, as in the examples of creative metaphors we have seen above. Finally, we will encounter some cases where we will not succeed in finding a way of expressing the same meaning, mostly in the cases of metonymies and dead metaphors.

\section{Conclusion}


Measure words have undergone a continuous dynamism throughout Chinese language history. In the beginning their use was optional but gradually became compulsory. The number of measure words and their co-occurrence with nouns have changed: many are not in use any more, others are used differently. We should assume that this dynamism and grammaticalisation process will continue in the future. A translator simply cannot afford to ignore this language phenomenon.

When we translate between languages there are always things that can be translated easily and things that are difficult to translate. In the case of measure words, we have seen that there is a great variety of situations and functions, so we should analyse case by case to see how much information we are losing if we do not translate a measure word. Sometimes the loss in meaning will not be significant, sometimes we will find an equivalent structure or word and sometimes we will need to express the same idea in a different way. In any case we cannot say that Chinese measure words cannot be translated, as is often done.

Measure words can make a sentence vivid and descriptive and greatly enhance the effectiveness of the writing, but not every measure word in Chinese should or must be automatically rendered into its dictionary equivalent in another language. The translator should deal with them in a flexible way, trying to avoid a mechanical translation, since he or she always has the choice of creating his/her own metaphorical expressions. 
[...] Rather, it [language] emerges organically from the interaction of varied inherent and experiential factors -physical, biological, behavioral, psychological, social, cultural, and communicative- each the source of constraints and formative pressures. Because many of these factors are the same or very similar for all speakers, language structure evidences considerable universality and is quite amenable to prototypic characterization. At the same time, every language represents a unique and creative adaptation to common constraints and pressures as well as to the peculiarities nonetheless sensitive and individually tailored. (Langacker 1991: 1)

In this paper, we have shown with illustrative examples that the widespread belief that measure words are unique to Chinese and thus cannot be translated into Western languages is not true; that the habit of providing only one word in a foreign language for a given Chinese measure word is misleading, since the equivalents are not one to one; and, finally, that the idea that they are redundant disregards their cognitive and pragmatic role in communication as well as the fact that they are linked to both a given culture and the speaker's subjective way of seeing and experiencing facts.

As far as we know, Zhang Xiangqun is the only author so far that has approached Chinese measure words from the stylistic point of view. In this paper we have intended to go further by offering a completely new approach to 
studying them, which mainly integrates Cognitive Linguistics and Translation Studies. We believe that within both the field of Translation Studies and Sinology this new approach can be revealing in understanding how Chinese language works in the creation of metaphorical images, on one hand, and how we should transfer them into other languages, on the other.

\section{Notes}

\footnotetext{
${ }^{1}$ Chinese has a category of words with special expressive functions. With them, images are more vividly described; with them, expression of emotions is deeper; with them, colors are brighter; with them, the writer's style appears even more concise. (Zhang Xiangqun 1995).

${ }^{2}$ I would like to thank Jennie Vest for helping me translate the literary examples into English.

${ }^{3}$ Measure words are a class of words which have an artistic value. They mainly enhance the brightness of the language, vividly showing Chinese elegance through their own artistic strength, which is why their rhetorical functions cannot be underestimated. If we want to speak and write correctly, we should give them the importance they deserve. Obviously, taking them into account does not mean they should be used indiscriminately, since their indiscriminate use might lead to confusion and to the overall impoverishment of the language. If we use them correctly, our language will be expressed more accurately, graphically and vividly. (Zhang Xiangqun 1995).

${ }^{4}$ When we speak about rhetoric, there will probably be people who will immediately think of metaphor, personification, exaggeration and other rhetorical figures; at the same time a great number of adjectives, verbs and nouns will come to mind, but they will often forget about the rhetorical function of measure words. In fact, if we examine them in detail, in certain linguistic contexts, the rhetorical effects of measure words are not less important than those of other
} 
grammatical categories and, what is more, certain rhetorical phenomena have a very close relationship with measure words. (Zhang Xiangqun 1995).

\section{References}

Anderson, Elna. 1999. "Some Remarks on the Productivity of the Numeral Classifier System in Modern Standard Chinese". Lund University. [Manuscript]

Denny, J. Peter. 1976. “What Are Noun Classifiers Good for?”. In Papers from the $12^{\text {th }}$ Regional Meeting of the Chicago Linguistic Society. 122-132.

Denny, J. Peter. 1986. "The Semantic Role of Noun Classifiers". In Noun Classes and Categorization, C. Craig (ed), 297-308. Amsterdam and Philadelphia: John Benjamins.

Lackoff, George. 1987. Women, Fire and Dangerous Things: What Categories Reveal about the Mind. Chicago: University of Chicago Press.

Lackoff, George. 1995. "Reflections on Metaphor and Grammar”. In Essays in Semantics and Pragmatics, M. Shibatani and S. Thompson (eds), 133144. Amsterdam and Philadelphia: John Benjamins. Pragmatics \& Beyond. New Series, 32.

Lakoff, George. 1986. "Classifiers as a reflection of mind". In Noun Classes and Categorization, C. Craig (ed.), 13-51. Amsterdam: John Benjamins. 
Lakoff, George. 1987. "Image and Metaphors". In Metaphor and Symbolic Activity 2, 3: 219-222.

Lakoff, George and Johnson, Mark. 1980. Metaphors We Live By. Chicago: University of Chicago Press.

Langacker, Ronald W. 1987. Foundations of Cognitive Grammar: Theoretical Prerequisites. Vol 1. Stanford (California): Stanford University Press.

Langacker, Ronald W. 1990. Concept, Image and Symbol. The Cognitive Basis of Grammar. Berlin: Mouton de Gruyter. Cognitive Linguistics Research, 1.

Langacker, Ronald W. 1991. Foundations of Cognitive Grammar: Descriptive Application. Vol 2. Stanford (California): Stanford University Press.

Lee, Michael. 1988. "Language, Perception and the World". In Explaining Language Universals, J. A. Hawkings (ed.), 211-246. Oxford: Blackwell Ltd.

Lehrer, Adrienne. 1986. "English Classifier Constructions". In Lingua 68: 109148.

Loke, Kit-Ken. 1997. "The Grammaticalisation and Regrammaticalization of Chinese Numeral Classifier Morphemes”. In Journal of Chinese Linguistics 25 (1): 1-20.

Rovira, Sara. 1998. Diccionari de Mesuradors Xinesos: Ús i Traducciói al Català. Bellaterra: Servei de Publicacions Universitat Autònoma de Barcelona. Materials, 45. 
Rovira, Sara. 1999. Bases per a una Nova Classificació dels Mesuradors Xinesos amb Criteris Pedagògics. Pre-doctoral dissertation. Departament of Translation and Interpreting, Autonomous University of Barcelona.

Shao, Jingmin. 1993. "Liangci de Yuyi Fenxi Ji Qi yu Mingci de Shuangxiang Xuanze". In Zhongguo yuwen 3: 181-188.

Tabakowska, E. 1993. Cognitive Linguistics and Poetics of Translation. Tübingen: Gunter Narr Verlag. Language in Performance, 9.

Tai, James and Wang, Lianqing. 1990. "A Semantic Study of the Classifier Tiao". In Journal of the Chinese Language Teachers Association 25 (1): $35-56$.

Zhang, Xiangqun. 1995. Liangci xiuci shenmei lun. Xi'an: Shanxi Renmin Jiaoyu Chubanshe. 